\title{
Prevalence of small intestine bacterial overgrowth in patients with gastrointestinal symptoms
}

\author{
Carolina Piedade MARTINS ${ }^{1}$, Caio Henrique Amorim CHAVES ${ }^{1}$, Maurício Gustavo Bravim de CASTR0², \\ Isabel Cristina GOMES ${ }^{3}$ and Maria do Carmo Friche PASSOS $^{3}$
}

Received 22/10/2016

Accepted 21/12/2016

ABSTRACT - Background - Small intestine bacterial overgrowth is a heterogeneous syndrome characterized by an increase in the number and/or the presence of atypical microbiota in the small intestine. The symptoms of small intestine bacterial overgrowth are unspecific, encompassing abdominal pain/distension, diarrhea and flatulence. Due to the increased cost and complexity for carrying out the jejunal aspirate, the gold standard for diagnosis of the syndrome, routinely the hydrogen $\left(\mathrm{H}_{2}\right)$ breath test has been used, utilizing glucose or lactulose as substrate, which is able to determine, in the exhaled air, the $\mathrm{H}_{2}$ concentration produced from the intestinal bacterial metabolism. However, due to a number of individuals presenting a methanogenic microbiota, which does not produce $\mathrm{H}_{2}$, the testing on devices capable of detecting, concurrently, the concentration of exhaled $\mathrm{H}_{2}$ and methane $\left(\mathrm{CH}_{4}\right)$ is justified. Objective - This study aimed to determine the prevalence of small intestine bacterial overgrowth in patients with digestive symptoms, through a comparative analysis of breath tests of $\mathrm{H}_{2}$ or $\mathrm{H}_{2}$ and $\mathrm{CH}_{4}$ associated, using glucose as substrate Methods - A total of 200 patients of both sexes without age limitation were evaluated, being directed to a Breath Test Laboratory for performing the $\mathrm{H}_{2}$ test (100 patients) and of exhaled $\mathrm{H}_{2}$ and $\mathrm{CH}_{4}$ (100 patients) due to gastrointestinal complaints, most of them patients with gastrointestinal functional disorders. Results - The results indicated a significant prevalence of small intestine bacterial overgrowth in the $\mathrm{H}_{2}$ test and in the test of exhaled $\mathrm{H}_{2}$ and $\mathrm{CH}_{4}(56 \%$ and $64 \%$ respectively) in patients with gastrointestinal symptoms, and higher prevalence in females. It found further that methane gas was alone responsible for positivity in $18 \%$ of patients. Conclusion - The data found in this study is consistent with the findings of the current literature and underscores the need for using devices capable of capturing the two gases (exhaled $\mathrm{H}_{2}$ and $\mathrm{CH}_{4}$ ) to improve the sensitivity and hence the accuracy of small intestine bacterial overgrowth diagnosis in daily medical practice.

HEADINGS - Bacterial growth. Small intestine. Breath tests. Hydrogen. Methane.

\section{INTRODUCTION}

Small intestine bacterial overgrowth (SIBO) is a heterogeneous syndrome, which can be characterized by an increase in the number and/or presence of an atypical microbiota in the small intestine ${ }^{(5,15)}$. It is known that although the gold standard for the diagnosis of overgrowth is still the presence of $1 \times 10^{5}$ to $10^{6}$ colony forming units $/ \mathrm{mL}(\mathrm{cfu} / \mathrm{mL})$ in the jejunal aspirate, this definition has been challenged in the present scenario ${ }^{(2,5)}$. Khoshini and collaborators suggest that healthy individuals rarely have higher bacterial counts than $1 \times 10^{3} \mathrm{cfu} / \mathrm{mL}$, which should be the new threshold for definition of the syndrome ${ }^{(8)}$.

The real prevalence of this syndrome is not well known due to difficulties in defining and thus the very detection of $\mathrm{SIBO}^{(2)}$. However, studies suggest that SIBO is a very common clinical condition, especially in patients with impaired gastrointestinal motility or anatomical abnormalities in the digestive tract ${ }^{(5)}$. Thus, a high prevalence of overgrowth was observed in patients with functional gastrointestinal disorders, inflammatory bowel disease, liver diseases, pancreatic diseases, celiac disease, diabetes mellitus and neuromuscular diseases ${ }^{(3,12)}$. Furthermore, SIBO has been associated with certain clinical conditions including rosacea, hepatic encephalopathy, obesity, gastroparesis, Parkinson's disease, fibromyalgia, among many others ${ }^{(14,19,21)}$. It is believed that qualitative and quantitative alterations of the intestinal microbiota (dysbiosis) occur in all of these clinical conditions associated with chronic symptoms determining $\mathrm{SIBO}^{(5,14)}$. Thus, the bacterial overgrowth is almost always a secondary condition, and, if the underlying problem is not addressed and treated properly (which is not always possible), the chance of SIBO recurrence is very high, even after antibiotic therapy ${ }^{(16)}$. In such cases, the need for repeated cycles of antibiotics is frequent to improve the intestinal symptomatology ${ }^{(9)}$.

The examination considered the gold standard for SIBO diagnosis is the jejunal aspirate culture, which is not routinely performed because it requires a complex technique and is costly ${ }^{(15)}$. In clinical practice, the most widely used method is the Hydrogen $\left(\mathrm{H}_{2}\right)$ breath test which has good sensitivity and specificity for the diagnosis ${ }^{(5,15,21)}$. This indirect and non-invasive test that uses glucose or lactulose as 
a substrate, is able to determine in the exhaled breath, the concentration of $\mathrm{H}_{2}$ produced from the intestinal bacterial metabolism. However, approximately 8 to $27 \%$ of individuals do not produce $\mathrm{H}_{2}$, due to the presence of methanogenic microbiota, which results in a significant percentage of false negative results ${ }^{(1,7,18)}$. For this reason, there has been a recommendation to perform the test in modern equipment capable of detecting, concomitantly, the concentration of exhaled $\mathrm{H}_{2}$ and methane $\left(\mathrm{CH}_{4}\right)$, making it more sensitive and more acurate ${ }^{(5,15,21)}$. Most studies point out that the diagnostic accuracy of the breath test using glucose is higher compared to that using lactulose $\mathrm{e}^{(20)}$.

Breath tests capable of identifying exhaled gases begin with acquiring the jejunal sample (baseline) for the measurement of $\mathrm{H}_{2}$ and/or $\mathrm{CH}_{4}$ in the exhaled air $^{(6)}$. After determining the baseline value, which is generally less than 10 parts per million (ppm), the patient ingests the carbohydrate that will be tested on the recommended dose (20 grams of lactulose in $250 \mathrm{ml}$ of water and 25 to $50 \mathrm{~g}$ glucose in $250 \mathrm{mg}$ of water $)^{(21)}$. The test will be considered normal if a significant increase in $\mathrm{H}_{2}$ and/or $\mathrm{CH}_{4}$ concentration does not occur in the expired air (less than $12 \mathrm{ppm}$ increase over the baseline value). It is important to observe and analyze possible symptoms that patients may present during the test ${ }^{(5,21)}$.

SIBO treatment is empirical, recommending the use of broad spectrum antibiotics for 10 to 14 days (quinolone, metronidazole, Amoxycillin, tetracycline). The antibiotic of choice considered is rifaximin, which has low systemic absorption and minimal collateral effects ${ }^{(13,16,17)}$. This drug has been shown to be more effective and safer in many studies, but is not yet available in Brazil ${ }^{(12)}$. Thus, it is recognized that, currently, the emerging need to develop a systematic and consensual approach to the diagnosis and treatment of SIBO $^{(16,19)}$

This study aimed to determine the prevalence of SIBO in patients with digestive symptoms, through a comparative analysis of breath tests using $\mathrm{H}_{2}$ or $\mathrm{H}_{2}$ and $\mathrm{CH}_{4}$. It is intended to infer whether, in fact, the tests on devices able to detect both gases in exhaled air $\left(\mathrm{H}_{2}\right.$ and $\left.\mathrm{CH}_{4}\right)$ are cost-effective and necessary for the diagnosis of SIBBO.

\section{METHODS}

A retrospective observational study was made, that evaluated the data and the results of breath tests using $\mathrm{H}_{2}$ or $\mathrm{H}_{2}$ and $\mathrm{CH}_{4}$ performed in a Breath Test Laboratory in Belo Horizonte (Cemad). This is the only service that has the breath test device able to detect exhaled $\mathrm{H}_{2}$ and $\mathrm{CH}_{4}$ in this city $\left(\mathrm{GastroCH} 4 \mathrm{ECK}^{\mathrm{TM}}\right)$. The project was approved by the Ethics Committee of the Medical Sciences Faculty Research in the resolution number 46290015.9.0000.5134.

The patients who underwent these tests and from which will be made the interpretation of the results, were sent to the laboratory due to presenting gastrointestinal symptoms and clinical suspicion of SIBO. Spreadsheets were constructed detailing the results of breath tests using only $\mathrm{H}_{2}$ and the $\mathrm{H}_{2}$ and $\mathrm{CH}_{4}$. The results confirmed or disproved the SIBO diagnostic through a quantitative assessment of the exhaled gases (value described in ppm, i.e. parts per million) and also through the evaluation of the presence or absence of symptoms reported by patients during the course of the respective tests. Such symptoms, properly described in the analyzed results of the tests were stratified as mild (only one reported symptom), moderate (two symptoms reported) and severe (three or more symptoms reported).
We evaluated the results of the breath tests from patients of both sexes without age limitation, referred to conduct such tests because of gastrointestinal complaints such as abdominal pain and/ or discomfort, flatulence, bloating, diarrhea, intestinal constipation, among others. A convenience sample which included all the results of the exhaled $\mathrm{H}_{2}$ and $\mathrm{CH}_{4}$ test held since the implementation of this breath test at the clinic for a year and a half (100 patients) was used. Similarly, the same number of patient test results that only performed the exhaled $\mathrm{H}_{2}$ test during that same period, selected consecutively and randomly (100 patients) was also evaluated. For greater uniformity in the interpretation of the results, we included only the results of patients who underwent the test using glucose as a substrate, excluding the results of those who took the test with lactulose as substrate.

The results were reviewed and analyzed by the interpretation of the figures obtained from the excretion of $\mathrm{H}_{2}$ and/or $\mathrm{H}_{2}$ and $\mathrm{CH}_{4}$ during the 2 hours that the test was performed. The patient results of $\mathrm{H}_{2}$ breath tests considered positive were those who had an increase in excretion of $\mathrm{H}_{2}$ in at least $12 \mathrm{ppm}$ relative to the baseline value, obtained before the substrate intake (glucose). Correspondingly, the patient results of $\mathrm{H}_{2}$ and $\mathrm{CH}_{4}$ breath tests considered positive were those who had increase in excretion of $\mathrm{H}_{2}$ or $\mathrm{CH}_{4}$ or both gases in at least $12 \mathrm{ppm}$ relative to the baseline value. Furthermore, an analysis was done of the symptoms description reported by patients during the whole period in which the tests were performed, in addition to the proper stratification as previously mentioned.

The data is presented by absolute and relative frequencies. The association between the results of breath tests in relation to gender and the occurrence of symptoms was assessed by Fisher's exact test. Statistical analyzes were carried out in the free software $\mathrm{R}$ version 3.1 .3 and $P$ values less than 0.05 were considered significant $(5 \%$ significance level).

\section{RESULTS}

The sample consisted of 200 consecutive results of breath tests of patients with clinical suspicion of SIBO. We selected 100 results of patient tests who only performed the exhaled $\mathrm{H}_{2}$ test and 100 patient results who underwent the exhaled $\mathrm{H}_{2}$ and $\mathrm{CH}_{4}$ test in the same period.

We found that the $\mathrm{H}_{2}$ and the $\mathrm{H}_{2}$ and $\mathrm{CH}_{4}$ exhalation tests were performed predominantly in women, accounting for $66 \%$ and $72 \%$ of samples, respectively.

It was observed that 56 results $(56 \%)$ of exhaled $\mathrm{H}_{2}$ breath tests were positive for SIBO. In addition, $63 \%$ of them had reported intestinal symptoms during the tests, with $16 \%$ classified as severe symptoms, $12 \%$ classified as moderate and $35 \%$ as mild symptoms. The time required for the test to became positive ranged from 15 to 120 minutes between the analyzed results. We also observed the difference of the baseline value and the maximum peak of exhaled $\mathrm{H}_{2}$ which ranged between $12-85 \mathrm{ppm}$ in these analyzed results.

The analysis of the test results from patients who underwent the exhaled $\mathrm{H}_{2}$ and $\mathrm{CH}_{4}$ test showed that 64 patients $(64 \%)$ tested positive for SIBO. In addition, there were reports of intestinal symptoms in $48 \%$ of the results of the analyzed tests, $15 \%$ were classified as severe symptoms, $13 \%$ as moderate symptoms and $20 \%$ as mild symptoms. The time required for the test positivity ranged from 15 to 120 minutes for $\mathrm{H}_{2}$ and 15 to 90 minutes for $\mathrm{CH}_{4}$, between the analyzed results. There was also the difference from 
the baseline and the maximum peak obtained from exhaled gases ranged between 12-144 ppm $\left(\mathrm{H}_{2}\right)$ and 14-50 $\mathrm{ppm}\left(\mathrm{CH}_{4}\right)$.

Table 1 shows the gender distribution and the occurrence of symptoms resulting from the $\mathrm{H}_{2}$ test. The occurrence of symptoms during the test was significantly associated with the test result $(P$ value 0.000 ), indicating that, among patients with a positive result, the proportion of those with symptoms $(80.4 \%)$ was significantly higher than among patients with negative results $(40.9 \%)$

TABLE 1. Gender distribution and symptoms occurrence for test result of $\mathrm{H}_{2}$ exhale test employing glucose as a substrate

\begin{tabular}{|c|c|c|c|c|c|}
\hline \multirow{2}{*}{ Variables } & \multicolumn{2}{|c|}{ Positive $(n=56)$} & \multicolumn{2}{|c|}{ Negative $(n=44)$} & \multirow{2}{*}{$P$-value } \\
\hline & $\mathrm{n}$ & $\%$ & $n$ & $\%$ & \\
\hline Gender & & & & & 1.000 \\
\hline Female & 37 & 66.1 & 29 & 65.9 & \\
\hline Male & 19 & 33.9 & 15 & 34.1 & \\
\hline Symptoms & & & & & 0.000 \\
\hline Symptomatic & 45 & 80.4 & 18 & 40.9 & \\
\hline Asymptomatic & 11 & 19.6 & 26 & 59.1 & \\
\hline
\end{tabular}

Table 2 shows the distribution of gender and occurrence of symptoms resulting from the $\mathrm{H}_{2}$ and $\mathrm{CH}_{4}$ test. There was a significant association between the affirmation of both gases $\left(\mathrm{H}_{2}\right.$ and $\left.\mathrm{CH}_{4}\right)$ and gender $(P$-value 0.020$)$, indicating that the proportion of female patients with positive results $(100 \%)$ was significantly

TABLE 2. Gender distribution and symptoms occurrence for test result of $\mathrm{H}_{2}$ and $\mathrm{CH}_{4}$ exhale test employing glucose as a substrate

\begin{tabular}{|c|c|c|c|c|c|}
\hline \multirow{2}{*}{ Variables } & \multicolumn{2}{|c|}{ Positive } & \multicolumn{2}{|c|}{ Negative } & \multirow{2}{*}{$P$-value } \\
\hline & $\mathrm{n}$ & $\%$ & $\mathrm{n}$ & $\%$ & \\
\hline Positive only for $\mathrm{H}_{2}$ & 36 & & 36 & & \\
\hline Gender & & & & & 0.454 \\
\hline Female & 26 & 72.2 & 22 & 61.1 & \\
\hline Male & 10 & 27.8 & 14 & 38.9 & \\
\hline Symptoms & & & & & 0.814 \\
\hline Symptomatic & 19 & 52.8 & 17 & 47.2 & \\
\hline Asymptomatic & 17 & 47.2 & 19 & 52.8 & \\
\hline Positive only for $\mathrm{CH}_{4}$ & 18 & & 36 & & \\
\hline Gender & & & & & 0.359 \\
\hline Female & 14 & 77.8 & 22 & 61.1 & \\
\hline Male & 4 & 22.2 & 14 & 38.9 & \\
\hline Symptoms & & & & & 1.000 \\
\hline Symptomatic & 8 & 44.4 & 17 & 47.2 & \\
\hline Asymptomatic & 10 & 55.6 & 19 & 52.8 & \\
\hline Positive $\mathrm{H}_{2}$ and $\mathrm{CH}_{4}$ & 10 & & 36 & & \\
\hline Gender & & & & & 0.020 \\
\hline Female & 10 & 100.0 & 22 & 61.1 & \\
\hline Male & 0 & 0.0 & 14 & 38.9 & \\
\hline Symptoms & & & & & 0.735 \\
\hline Symptomatic & 4 & 40.0 & 17 & 47.2 & \\
\hline Asymptomatic & 6 & 60.0 & 19 & 52.8 & \\
\hline
\end{tabular}

higher than among patients with negative results $(61.1 \%)$. The isolated affirmation of exhaled $\mathrm{H}_{2}$ was not significantly associated with gender ( $\mathrm{p}$-value 0.454 ) or with the occurrence of symptoms $(P$-value 0.814$)$. Similarly, the isolated affirmation of methane was not significantly associated with gender $(P$-value 0.359$)$ nor the occurrence of symptoms ( $P$-value 1.000). In cases of simultaneous affirmation of $\mathrm{H}_{2}$ and $\mathrm{CH}_{4}$, there was also no significant association with the symptoms ( $P$-value 0.735$)$.

\section{DISCUSSION}

There is a misconception that SIBO is a rare clinical condition that occurs only in a small number of patients with anatomic abnormalities of the proximal digestive tract or severe digestive motility disorders ${ }^{(18)}$. Recent studies show that an excessive number of bacteria is found in several gastrointestinal disorders, surviving especially in patients with celiac disease, inflammatory bowel disease, chronic liver diseases and gastrointestinal functional disorders, especially in the irritable bowel syndrome ${ }^{(4,14)}$.

It is known that the prevalence of SIBO in healthy volunteers is lower when compared to symptomatic patients, especially those patients with inflammatory bowel disease, irritable bowel syndrome and abdominal ${ }^{(7,11)}$ distension syndrome. The presence of overgrowth, as detected by the exhaled $\mathrm{H}_{2}$ test has been described in $0-12.5 \%$ in the asymptomatic ${ }^{(20)}$ volunteer group. However, it is important to note that the actual prevalence of the syndrome is not well known due to remaining difficulties for its diagnosis in daily practice ${ }^{(2)}$.

In the present study, we observed a higher prevalence of females in patients with intestinal symptoms in the two analyzed tests. However, a study by Erdogan et al. ${ }^{(15)}$ demonstrated that gender does not influence the presence of overgrowth, not corroborating with our results. What probably differs from our results is that most patients referred to such tests were suffering from gastrointestinal functional disorders, especially irritable bowel syndrome, known to be more prevalent in women, at a ratio of $4: 1^{(10,11)}$.

The study from Erdogan et al. also showed that the prevalence of bacterial overgrowth in patients with intestinal symptoms (diarrhea and flatulence, without changes in digestive endoscopy) was only $27.3 \%$ when using the $\mathrm{H}_{2}$ and $\mathrm{CH}_{4}$ test ${ }^{(6)}$. However, when the duodenal culture (gold standard for the diagnosis of SIBO) was also performed this prevalence increased to $44.6 \%$. These authors concluded in the end that $65.5 \%$ of patients reporting gastrointestinal symptoms during the test had an overgrowth of microorganisms in the small intestine. In our study, we found a prevalence of $64 \%$ positivity overgrowth, a very similar rate to that acquired by North American researchers ${ }^{(18)}$.

We observed in this study that the presence or absence of digestive symptoms while performing both tests shows a direct correlation with the result thereof. In patients who tested positive for SIBO, symptom reporting was significantly more frequent than in those with negative results.

Given that the $\mathrm{H}_{2}$ and $\mathrm{CH}_{4}$ are produced in the intestine by microorganisms that degrade carbohydrates, the breath test which detects these gases is carried out in order to evaluate the presence of bacterial overgrowth ${ }^{(18,22)}$. Thus, the use of the test that identifies the production of both gases is essential for greater accuracy in the diagnosis of the syndrome. The addition of methane to the exhaled $\mathrm{H}_{2}$ test increases the sensitivity for the diagnosis of SIBO, allowing detection of the syndrome in a subgroup of individuals that do not produce $\mathrm{H}_{2}$, but produce $\mathrm{CH}_{4}$ as a major byproduct 
of carbohydrate fermentation ${ }^{(16)}$. According to numerous studies that identified $\mathrm{CH}_{4}$ exhaled in breath tests, it is estimated that $30 \%-62 \%$ of healthy individuals excreting this $\mathrm{Gas}^{(6,22)}$. As about $15 \%$ of humans do not produce $\mathrm{H}_{2}$, devices capable of detecting both gases, greatly increase the sensitivity of the test, reducing false negative results.

In this study the data analyzed was from two breath tests using different samples. SIBO prevalence was $56 \%$ in the tests conducted in apparatus that detects only expired $\mathrm{H}_{2}$ and $64 \%$ in those performed in another apparatus capable of detecting both exhaled $\mathrm{H}_{2}$ and $\mathrm{CH}_{4}$. In this last test, it was found that methane was solely responsible for positivity in $18 \%$ of patients, while the $\mathrm{H}_{2}$ was solely responsible for $36 \%$ of this total. Together, these gasses were responsible for the positivity in $10 \%$ of the sample.

Our results show that approximately $20 \%$ of patients identified with SIBO only got their SIBO diagnosis by methane identification in the exhaled gas, which is consistent with the results found in the literature ${ }^{(6,16,20)}$. Thus, it is essential that the breath tests to diagnose SIBO be performed on devices capable of identifying the exhaled $\mathrm{H}_{2}$ and $\mathrm{CH}_{4}$, in order to increase sensitivity and diagnostic accuracy.

\section{CONCLUSION}

The data obtained in our study are consistent with those of the most recent literature on this topic. We proved the importance of utilizing the breath test that identifies the exhaled $\mathrm{H}_{2}$ and $\mathrm{CH}_{4}$ in order to increase the diagnostic accuracy of small intestine bacterial overgrowth. Our results confirm previous findings that showed that $15 \%$ to $20 \%$ of individuals do not produce hydrogen gas in their intestine.

It was also possible to observe a high prevalence of SIBO in patients with digestive symptoms during the two hours that the test is performed. Furthermore, we found that the presence and severity of symptoms during the making thereof is more frequent in patients with a positive result, correlating directly with the diagnosis of bacterial overgrowth.

Our study reinforces the need for routine introduction, in our midst, of devices able to detect both gases $\left(\mathrm{H}_{2}\right.$ and $\left.\mathrm{CH}_{4}\right)$ for the most accurate diagnosis of SIBO, increasing thus the sensitivity and reliability of this test, with a significant reduction of false negative results.

\section{Authors' contributions}

Martins CP participated in the study design, data interpretation, manuscript writing, revised the final version of the manuscript to be published; participated in the protocol/project development, data collection and manuscript writing/editing; Chaves CHA participated in the protocol/project development, data collection and manuscript writing/editing; Castro MGB participated in the study design and performing the tests; Gomes IC participated in the statistical analysis; Passos MCF was a coordinator, participated in the study design, data interpretation, manuscript writing, and she revised the final version of the manuscript to be published. Study supervision: Passos MCF.

Martins CP, Chaves CHA, Castro MGB, Gomes IC, Passos MCF. Prevalência de supercrescimento bacteriano do intestino delgado em pacientes com sintomas intestinais funcionais. Arq Gastroenterol. 2017;54(2):91-5.

RESUMO - Contexto - O supercrescimento bacteriano do intestino delgado é uma síndrome heterogênea, caracterizada pelo aumento no número e/ ou presença de uma microbiota atípica no intestino delgado. Os sintomas do supercrescimento bacteriano do intestino delgado são inespecíficos englobando quadro de dor/distensão abdominal, diarreia e flatulência. Devido ao maior custo e complexidade para a realização do aspirado jejunal, padrão ouro para o diagnóstico da síndrome, tem sido utilizado rotineiramente o teste do hidrogênio $\left(\mathrm{H}_{2}\right)$ expirado, utilizando glicose ou lactulose como substrato, que é capaz de determinar, no ar expirado, a concentração de $\mathrm{H}_{2}$ produzida a partir do metabolismo bacteriano intestinal. Entretanto, em decorrência de uma parcela de indivíduos apresentar uma microbiota metanogênica, não produtora de $\mathrm{H}_{2}$, justifica-se a realização do teste em aparelhos capazes de detectar, concomitantemente, a concentração de $\mathrm{H}_{2}$ e metano $\left(\mathrm{CH}_{4}\right)$ expirados. Objetivo - $\mathrm{O}$ presente estudo teve como objetivo determinar a prevalência de supercrescimento bacteriano do intestino delgado em pacientes com sintomas digestivos, através de uma análise comparativa dos testes respiratórios empregando $\mathrm{H}_{2}$ ou $\mathrm{H}_{2}$ e $\mathrm{CH}_{4}$ associados, utilizando a glicose como substrato. Métodos - Foram avaliados 200 pacientes de ambos os sexos, sem limitação de idade, encaminhados a um Laboratório de Teste Respiratório para realização do teste de $\mathrm{H}_{2}(100$ pacientes) e de $\mathrm{H}_{2}$ e $\mathrm{CH}_{4}$ expirados (100 pacientes) devido a queixas gastrointestinais, a maioria deles portadores de distúrbios funcionais gastrointestinais. Resultados - Os resultados obtidos indicaram uma significativa prevalência do supercrescimento bacteriano do intestino delgado no teste do $\mathrm{H}_{2}$ e no teste do $\mathrm{H}_{2}$ e $\mathrm{CH}_{4}$ expirados ( $56 \%$ e 64\%, respectivamente) em pacientes com sintomas gastrointestinais, além de maior predominância no sexo feminino. Constatou-se ainda, que o gás metano foi isoladamente responsável pela positividade em $18 \%$ do total de pacientes. Conclusão - Os dados encontrados no presente estudo demonstram condizentes com os achados da literatura atual e reforçam a necessidade da utilização de aparelhos capazes de captar os dois gases $\left(\mathrm{H}_{2}\right.$ e $\mathrm{CH}_{4}$ expirados) para melhorar a sensibilidade e, consequentemente, a acurácia do diagnóstico de supercrescimento bacteriano do intestino delgado na prática médica diária.

DESCRITORES - Crescimento bacteriano. Intestino delgado. Testes respiratórios. Hidrogênio. Metano. 


\section{REFERENCES}

1. Attaluri A, Jackson M, Valestin J, Rao SS. Methanogenic flora is associated with altered colonic transit but not stool characteristics in constipation without IBS. Am J Gastroenterol. 2010;105:1407-11.

2. Cole C, Ziegler T. Small Bowel bacterial overgrowth: a negative factor in gut adaptation in pediatric SBS. Curr Gastroenterol Rep. 2007;9:456-62.

3. Costa MBG, Azeredo Jr. IL, Marciano RD, Caldeira LM, Bafutto M. Evaluation of small intestine bacterial overgrowth in patients with functional dyspepsia through H2 breath test. Arq Gastroenterol. 2012;49:279-83.

4. Costello BPJ, Ledochowski M.; Ratcliffe NM. The importance of methane breath testing: a review. J Breath Res. 2013; 7:7-16.

5. Dukowicz AC, Lacy BE, Levine GM. Small Intestinal Bacterial Overgrowth: A Comprehensive Review. Gastroenterol Hepatol (N Y). 2007;3:112-22.

6. Erdogan A, Rao SSC, Gulley D, Jacobs C, Lee YY, Badger C. Small intestinal bacterial overgrowth: duodenal aspiration $v s$ glucose breath test. Neurogastroenterol Motil. 2015;27:481-9.

7. Gasbarrini A, Corazza GR, Gasbarrini G, Montalto M, Di Stefano M, Basilisco $\mathrm{G}$, et al. Methodology and indications of H2-breath testing in gastrointestinal diseases: the Rome Consensus Conference. Aliment Pharmacol Ther. 2009;29:1-49.

8. Khoshini R, Dai SC, Lezcano S, Pimentel M. A systematic review of diagnostic tests for small intestinal bacterial overgrowth. Dig Dis Sci. 2008;53:1443-54.

9. Lacy LB, Mearin F, Chang L, Chey WD, Lembo AJ, Simren M, et al. Rome IV: Bowel Disorders. Gastroenterology. 2016;150:1393-1407e5.

10. Lovell RM, Ford AC. Global prevalence of and risk factors for irritable bowel syndrome: a meta-analysis. Clin Gastroenterol Hepatol. 2012;10:712-21.e4.

11. Mitsui T, Kagami H, Kinomoto H, Ito A, Kondo T, Shimaoka K. Small bowel bacterial overgrowth and rice malabsorption in healthy and physically disabled older adults. J Hum Nutr Diet. 2003;16:119-22.
12. Passos MCF, Ramos AFP. Supercrescimento Bacteriano do Intestino Delgado. Rio de Janeiro: Editora Graffito; 2014, p.79-90.

13. Pimentel M. Review article: potential mechanisms of action of rifaximin in the management of irritable bowel syndrome with diarrhea. Aliment Pharmacol Ther. 2016;43:37-49.

14. Quera RP, Quigley EMM, Madrid AMS. Small intestinal bacterial overgrowth. An update. Rev Méd Chile. 2005;133:1361-70. Available from: http://www.scielo. cl/scielo.php?script=sci_arttext\&pid=S0034-98872005001100013\&lng=es

15. Quigley EM. Small intestinal bacterial overgrowth: what it is and what it is not. Curr Opin Gastroenterol. 2014;30:141-6.

16. Rezaie A, Pimentel M, Rao SS. How to Test and Treat Small Intestinal Bacterial Overgrowth: an Evidence-Based Approach. Curr Gastroenterol Rep. 2016;18:8.

17. Rivkin A, Rybalov S. Update on the Management of Diarrhea-Predominant Irritable Bowel Syndrome: Focus on Rifaximin and Eluxadoline. Pharmacotherapy. 2016;36:300-16.

18. Saad RJ, Chey WD. Breath testing for small intestinal bacterial overgrowth: maximizing test accuracy. Clin Gastroenterol Hepatol. 2014;12:1964-72.

19. Sachdev AH, Pimentel M. Gastrointestinal bacterial overgrowth: pathogenesis and clinical significance. Ther Adv Chronic Dis. 2013;4:223-31.

20. Shimura S, Ishimura N, Mikami H, Okimoto E, Uno G, Tamagawa Y, et al. Small Intestinal Bacterial Overgrowth in Patients with Refractory Functional Gastrointestinal Disorders. J Neurogastroenterol Motil. 2016;22:60-8.

21. Siddiqui I, Ahmed S, Abid S. Update on diagnostic value of breath test in gastrointestinal and liver diseases. World J Gastrointest Pathophysiol. 2016;7:256-65.

22. Triantafyllou K, Chang C, Pimentel M. Methanogens, methane and gastrointestinal motility. J Neurogastroenterol Motil. 2014;20:31-40. 